\title{
Analysis of Transparency in the Municipal Chambers of Pernambuco/Brazil Part of the Information Access Law
}

\author{
Jéssika Carolina Eurico de Albuquerque \\ Autarquia Educacional do Vale do São Francisco (AEVSF) \\ Raimundo Nonato Lima Filho \\ Autarquia Educacional do Vale do São Francisco (AEVSF) \\ Josué Nunes de Araújo Júnior \\ Autarquia Educacional do Vale do São Francisco (AEVSF) \\ Josaias Santana dos Santos \\ Autarquia Educacional do Vale do São Francisco (AEVSF)
}

Agnaldo Batista da Silva

Autarquia Educacional do Vale do São Francisco (AEVSF)

Received: May 7, 2018 Accepted: May 28, 2018 Online published: May 31, 2018

doi:10.5296/jpag.v8i2.13105 URL: https://doi.org/10.5296/jpag.v8i2.13105

\begin{abstract}
The aim of this study is to analyze the transparency of public information in electronic portals of Municipal Chambers of Pernambuco. It is a descriptive research with quali-quantitative approach, and the data collection procedure is documentary research. Websites of 169 Municipal Chambers of cities that have population beyond ten thousand inhabitants were analyzed, based on indicators proposed by the Information Access Law, in its first paragraph of Article 8. The compliance level was established through six indicators for which a grade criterion was determined: a point to each item that was observed and zero to when it was not observed. After descriptive statistics were carried out, it was observed that the obtained results reached $30 \%$ of compliance in ranking of the most transparent, which is a value
\end{abstract}


considered very low. Moreover, from analyzed variables (Population Size and Ranking; Population Size and Transparency; Ranking and total Revenue; Transparency and total Revenue) it was confirmed that only Population Size and Ranking have a positive relationship. Therefore, the compliance level of the Information Access Law is still in a remote stage from reaching transparency and it is justified by the amount of analyzed articles, bringing unsatisfactory results, considering the Law has been effective since 2012 .

Keywords: information access law, transparency, municipal chambers.

\section{Introduction}

Public resources disclosed by public agencies or entities enable citizens to know about the destination of such resources, intending to favor a better transparency level of public accounts, which must be legally made available in virtual communication means that are accessible to any user (Nunes, 2013). Thus, this article has the purpose of analyzing the compliance level of public information in electronic means of Municipal Chambers of Pernambuco.

According to Bairral, Silva and Alves (2015), navigation in electronic portals used by society is a means of communication with the rulers, with the necessity of gathering information on different government institutions, using a language adapted to any person.

Pursuant to the Federal Constitution, it is a duty of public agencies to transmit information, required by Law, to anyone who needs to acquire it, except the information that must be kept confidential (Brasil, 1988).

The most appropriate means of communication to interact with society is the internet, as it enables transparency of entities, since disclosure is required by Law. In addition to be an inspection way, it is also a technological advancement to obtain public information (Platt Neto, 2007).

Nowadays, Law no. 12.527/2011 makes available methods that must be observed by the three Branches of Government, assuring access to information to all users interested in government decisions, providing easy-to-understand language (Brasil, 2011).

In order to have access to information, different procedures were provided to offer services to the general public, enabling communication between interested individuals and the government, with the purpose of generating effectiveness in procedures, promoting greater efficiency in the evidence of information (Raupp \& Pinho, 2011).

In view of what was presented, this research aims to address the following problem: What is level of compliance to the Information Access Law made available by Municipal Chambers of Pernambuco?

The aim of this study is to analyze the transparency of public information in the electronic portals of Municipal Chambers of Pernambuco.

The relevance of this research consists in demonstrating if there is transparency of acts carried out by public agencies and entities, based on the Information Access Law found in virtual means of communication, providing society with more efficient social control. Thus, it 
is necessary to demonstrate commitment of public agencies regarding information disclosure, accessibility, and understanding by society.

The research is justified by the need to analyze the correlation between the following variables: Size of city and size of public revenue of the city, with level of public transparency of Municipal Chambers of Pernambuco. Therefore, it will be necessary to conduct a survey of all Municipal Chambers of the State of Pernambuco to know which are the most transparent and which are the least transparent, contributing to better social control. The article was developed in five sections: Introduction, Theoretical Foundation, Methodology, Analysis of Results, and Final Considerations.

\section{Theoretical Foundation}

\subsection{Transparency in Public Management}

According to Sacramento and Pinho (2007), the transparency of public information for society is of great relevance to democracy in the country. According to the authors, transparency of government actions contributes to reduce corruption, making both the State and population more democratic.

Democracy is consolidated through the Information Access Law. Thus, citizens have the imposed rights to information that are under control of government, and the publicity and transparency of government actions must be carried out (Bernardes, Santos \& Rover, 2015).

According to Angélico (2012), the word Transparency is linked to the set of information that presents quality and favors accountability. Therefore, the author states that a transparent government must be concerned with the way in which

information is made available, ensuring that the accuracy of facts is fully provided in case of any eventuality.

Campos (1990) explains that the word accountability still does not have an accurate translation to Portuguese. This can be understood by the lack of political knowledge, but its practice is seen as popular control.

To Cruz, Silva, and Santos (2009) the term accountability is aligned with requirements that citizens impose to the government in exchange for response to resources. Thus, the authors attest the possibility of a discussion about public policies between citizens and government.

Transparency and accountability are subjects of debate nowadays, as the participation of society contributes to the effective implementation of Public Administration, free from corruption, consequently benefiting democracy (Angélico, 2012). The author adds that agencies do not usually put in evidence the results obtained from public accounts.

Raupp, Andrade and Pinho (2015) state that it is essential for public management to present a model to coordinate strategies and acts to encourage access to information, offering accountability to those who disrespect the IAL devices. The virtual relationship of people in obtaining immediate information, reached through electronic means, contributing to reduce the difficulties found in information management (Raupp, Andrade \& Pinho, 2015). 
Platt Neto (2007) states that, according to the principle of openness, transactions related to government accounts must be provided by the entities, providing information of social benefit.

Society is the main way to fight corruption, as the more it is involved in government issues, better use the public resources will have (Bairral, Silva \& Alves, 2015).

The information made available in websites tends to minimize the number of requests for access, reducing the work and expenses generated by the management of requisition management in government agencies and entities, facilitating the relationship between citizens and government entities (Bernardes et al., 2015).

The access provided in social networks benefits good accountability practices, strengthening external control (Keunecke, Teles \& Flach, 2011). Within the definition of Raupp, Andrade and Pinho (2015), the term accountability is connected with power and governance system related to each State.

Barros and Fonseca (2014) state that the easiest intermediation between society and public management is through cities. Nevertheless, it is not always possible for cities to comply with Brazilian laws, as, in some cases, information is not properly comprehended.

The control agency is responsible for inspecting the course of public administration, and society must check if public actions have been efficiently carried out (Bairral etl al., 2015).

To Cruz, Silva, and Santos (2009), transparency of public accounts is of great relevance to society, as acts and facts carried out by managing authorities are demonstrated for better control by society, holding liable the managers who fail to comply with the regulations.

Souza et al., (2013) point out that transparency is the best way to extinguish corrupt attitudes, punishing managers who might hide such information required by Law. The authors claim that the data found are of difficult access to information users.

Jacques, Quintana, and Macagnan (2013) state that Transparency is seen as the strengthening of communication with society. Thus, social participation enables the knowledge of public resources available in our country in all spheres.

With advent of the Federal Constitution of 1988, the participation of society in government practices became more frequent, enabling more transparency (Arruda \& Teles, 2010).

\subsection{Rendering of Accounts}

Keunecke et al. (2011) state in their research that, with inclusion of Law No. 131/2009, Public Administration must render accounts of expenses of public

resources, providing a glossary and navigation manual, employing easy-to-understand language.

Arruda and Teles (2010) understand that public managers must render accounts, being transparent in government acts, informing the population about all incurred expenses related to management expenses. 
The expansion of characteristics included in the rendering of accounts favors the information user with the ease of operationalizing the monitoring of public resources. In some cases the Law is not complied, causing a lack of accountability construction. In this sense, it is the responsibility of both inspection and society to require some public managers to disclose information related to budgetary and financial data (Raupp \& Pinho, 2014).

Raupp and Pinho (2013) state there is no acknowledgment about the relevance of websites being always updated. They are seen as electronic notice boards, not contributing to advancement of transparency.

Souza et al. (2013) state that accounting sectors in cities are disorganized, there is no disclosure of information, and nobody is penalized for that.

\subsection{The Information Access Law}

The Information Access Law employs mechanisms used by all spheres, enabling citizens to know data, intending to - according to Public Administration - comply with the following instructions: In general, publicity and, as an exception, confidentiality; the disclosure of public information; the use of technology; transparency (Brasil, 2011).

After effectiveness, the Law provided the commitment of agencies and entities to disclose all acts carried out by managers in social means of communication, which was already required by previous Laws, as it was the case of Transparency Law that superseded the Fiscal Liability Law, providing the population with a broader view of the reality of their actions (Brasil, 2011).

Comin et al., (2016) explain that the IAL created devices to favor citizens to obtain

information through publicity, encouraging Active Transparency, regardless of requirement.

Houch, Rigui and Silva (2012) state that, with the advent of the Information Access Law, the published demonstrations are fully used, considering that the internet is an efficient tool for interaction in the social environment.

Angélico (2012) defends in his research that the Information Access Law introduced the importance of providing transparency and strengthening democratic accountability, using tools so that the government is more accessible and responsive to different countries.

Civil society also contributes to the implementation of the Law, participating in supervision in websites, as the requirements by Brazilian Law are still precarious, being necessary more strict attitudes to companies who fail to comply with what is established according to the compliance with their legal obligations (Angélico, 2012). To Comin et al., (2016) the State is partially responsible for the adequacy of information, as the cities which do not properly fulfill their obligations should be penalized. According to the authors, the publication of information should already be adjusted to all the obligations required by the norm.

It is required that government entities disclose their information in websites, and it should contain research tools that allow the access to information in a transparent way, facilitating comprehension and assuring the truth in information (Brasil, 2011). 
According to the IAL, agencies and entities must have adequate conditions to assist, inform, and file the requests related to the demand for public information requests (Brasil, 2011).

With the introduction of IAL, Raupp and Pinho (2014) defend the value of electronic means because it is through them that both citizens and government entities communicate in a fast and safe way, exercising citizenship and establishing a democratic vision.

The websites of Municipal Chambers provide information to any citizen interested in government accounts, with the purpose of attesting that the expenses, related to their

cities, States and Federal Government are being applied properly, providing better social control of available resources (Cruz et al., 2012).

It is emphasized through Article 8, paragraph 4 of IAL that the cities with population of up to 10.000 inhabitants are exempt from mandatory publication in social networks, referring to paragraph 2 of Article 8 (Brasil, 2009).

Also regarding the aforementioned Complementary Law, the obligation of publication in relation to budgetary and financial application is provided according to Article 73-B of such Law, considering the required terms, which are as follows: To all government spheres the required term is one year, if they have over one hundred thousand inhabitants; two years to cities that have between fifty thousand and one hundred thousand inhabitants; four years to cities that have up to fifty thousand inhabitants (Brasil, 2009).

Hoch, Rigui, and Silva (2012) highlight that technological effects of information intend to achieve Transparency, providing growth in the Public Administration performance and reducing government costs.

To Bairral, Silva and Alves (2015), Transparency is understood as a tacit social contract, in which citizens issue an activity to public manager, observing if acts practiced by the management are being efficiently conducted, enabling citizens to effectively carry it out so there is a social contract.

Hobold (2017) believes that instructions that facilitate access to websites should be provided, thus avoiding corruption and uniting citizens and government in public affairs.

Jacques, Quintane and Macagnan (2013) highlight that, it was upon enactment of the Information Access Law that democracy in Brazil started, preventing corruption and encouraging better public management.

Despite the participation of population in governmental policies, the rate of uninformed people is rather high, and lack of disclosure also makes it difficult to manage such information (Campos, Paiva \& Gomes, 2013).

According to the IAL, the disclosure should include information on: financial

transferences, expenses directed to public expenditures, as well as bidding processes, data on programs, information about actions, data on projects, among other matters that the Law allows to inform to the citizens (Brasil, 2011). 


\section{Methodology}

This article is of applied nature with the objective of exploratory research. According to Gil (2008), this type of research provides a broader view related to a specific reality, involving a bibliographical survey. From the point of view of problem, this research will employ a quali-quantitative approach.

The Theoretical Foundation was developed through books and articles related to the subject, and the research was conducted through previously elaborated material. This type of research is a bibliographic research (Gil, 2008).

The adopted method will be inductive, which, according to Gil (2008), is confirmed through observation of real cases.

The empirical object of the analyzed research refers to the electronic portals of Municipal Chambers of the State of Pernambuco. Thus, there will be 185 Municipal Chambers to conduct the research. The addresses will be identified through the Google website.

Data collection will be performed through observation protocol. According to Creswell (2010) observation protocol is used to register information considered important. In the case of this research, an observational protocol will be applied based on the regulation established by the IAL. For this reason, it will be conducted a survey of data to know what is actually exercised within what the Information Access Law requests. As it employs sources of documents determined by legislation, the research is of documentary origin (Marconi \& Lajatos, 2003).

This study intends to develop the issue of Transparency of Municipal Chambers of Pernambuco Cities. The data will be analyzed through the technique of descriptive analysis; according to studies by Raupp, Andrade and Pinho (2015), the essence of a descriptive research is to establish the description of a specific population and its variables.

From Regulation of the IAL, the following conditions were established to analyze data according to paragraph 1 of article 8, which are: Register of competences and business structure; addresses, telephone numbers and customer service hours; Transfers or on lending; Expenses; bidding data; Data of programs, projects, actions, and works; Responses of society (Brasil, 2011).

A grade criterion will be established for each indicator identified in websites of each Municipal Chamber. After finding results, with respective grades, it will be identified, through Ranking, which Municipal Chambers are the most transparent and which are the least transparent.

Therefore, a percentage of compliance will be determined in relation to the Law; that is, those that are above $50 \%$ of compliance to Law will be in the group of most transparent, and those that are below $50 \%$ of compliance to Law will be in the group of least transparent.

Subsequently, a data survey will be conducted considering the following variables: Size of city and size of public revenue. Being the variables identified through websites of IBGE and Municipal Chambers of each analyzed city, respectively. 


\section{Macrothink}

Journal of Public Administration and Governance

ISSN 2161-7104

2018, Vol. 8, No. 2

From this data survey, it will be necessary to establish a correlation between variables and groups of cities defined as most transparent and least transparent, in order to know if there is any relationship between them, such as: Do most transparent Municipal Chambers have a relationship with more or less inhabited cities? Do least transparent Municipal Chambers have any relationship with size of public revenue? Those matters and some others will be analyzed below in the Analysis of Results Section.

\section{Analysis of Results}

\subsection{Descriptive Analysis}

In order to conduct this research, 185 Pernambuco Municipal Chambers were considered, according to IBGE data. Among analyzed cities, those with more than 10.000 inhabitants were considered. The delimitation of the research is justified by the Information Access Law, through Article 8, paragraph 4, which states that cities with less than 10.000 inhabitants are exempt from the disclosure of information on websites. With this cut, 169 cities remained, from which three Municipal Chambers were excluded due to technical problems: Petrolândia, Lagoa dos Gatos, and Casinhas. In view of the exposed, the total amount of analyzed cities was 166. The data collection period corresponded to months of August and September 2017.

Analyzed Municipal Chambers were segregated in the following data by size: Sixty cities had size between 10 to 20 thousand inhabitants; seventy four cities had size between 20 to 49 thousand inhabitants; twenty two cities had size between 50 to 99 thousand inhabitants; seven cities had size between 100 to 299 thousand inhabitants; four cities had size between 300 to 499 thousand inhabitants; only two cities had more than 500 thousand inhabitants, which are: Recife and Jaboatão dos Guararapes, being a total sample of 169 cities. Table 1 demonstrates the descriptive statistics related to size of cities.

Table 1. Descriptive Statistics

\begin{tabular}{lcc}
\hline $\begin{array}{l}\text { Number } \\
\text { inhabitants }\end{array}$ & Amount of cities & Frequency \\
\hline 10 to 20 thousand & 60 & $36 \%$ \\
20 to 49 thousand & 74 & $44 \%$ \\
50 to 99 thousand & 22 & $13 \%$ \\
100 to 299 & 7 & $4 \%$ \\
thousand & & \\
300 to 499 & 4 & $2 \%$ \\
thousand & 2 & $1 \%$ \\
Over 500 thousand & 169 & $100 \%$ \\
\hline Total & & \\
\hline
\end{tabular}


Source: Own preparation, according to IBGE.

The data survey conducted in the electronic portals of each Municipal Chamber intends to analyze the compliance of public information established by the Information Access Law, facilitating access by users and reducing government expenses with provision of this information.

The items used in the data survey, according to paragraph 1 of Article 8 of such Law are: Registration of competences and organizational structure of each analyzed Municipal Chamber, addresses and telephone numbers of respective units and customer service hours, being located in places of easy access. The records of onlending or financial transfers must also be included in the portals with their respective values; Registration of expenses; Bidding information; Data of programs, actions, projects, and works; Responses to questions by society (Brasil, 2011).

Table 2 informs the compliance percentage with regard to the Law. It can be observed that $70 \%$ of Municipal Chambers of Pernambuco were considered not transparent and only 30\% of them were considered transparent.

Table 2. Level of Observance of Law

Quantity of observed items

Transparency level Number of \% Municipal Chambers

1 to 3 Least transparent 11670

4 to 6 Most transparent 5030

Source: Own preparation, results of research.

The analysis of 166 cities led to conclusion that only $6.6 \%$ of Municipal Chambers met all requirements established by the IAL during the period of data collection. The transparency level reached $30 \%$ of compliance to such Law. On the other hand, 35.5\% of Municipal Chambers did not meet any of the requirements of the Law, obtaining a grade of 0 (zero). The results are similar to those of Comin et al., (2016) where it was stated that none of the Santa Catarina cities studied fully evidenced their information.

The grade zero was attributed to those Municipal Chambers that do not have a website, or have one that, at the moment of collection, was not working, either due to maintenance or error. Some websites had links, but did not make the information available. Twenty two Municipal Chambers obtained only grade one, complying only one item of Law, representing $13.3 \%$ of the research. Fifteen Municipal Chambers obtained grade two, representing $9 \%$ of data; Twenty Municipal Chambers obtained grade 3; Twenty seven Municipal Chambers obtained grade 4; Twelve Municipal Chambers obtained grade 5. Only eleven Municipal Chambers obtained grade six, totalizing $6.6 \%$ of the analysis. Thus, $70 \%$ of the Municipal Chambers had the lowest transparency levels within the studied period. To better 
understanding of research results, Table 3 sums up the submitted data:

Table 3. Distribution of research results

\begin{tabular}{|c|c|c|}
\hline Grade & $\begin{array}{l}\text { Number of } \\
\text { Chambers }\end{array}$ & City Frequency \\
\hline$\overline{0}$ & 59 & $35.5 \%$ \\
\hline 1 & 22 & $13.3 \%$ \\
\hline 2 & 15 & $9.0 \%$ \\
\hline 3 & 20 & $12.0 \%$ \\
\hline 4 & 27 & $16.3 \%$ \\
\hline 5 & 12 & $7.2 \%$ \\
\hline 6 & 11 & $6.6 \%$ \\
\hline Total & 166 & \\
\hline
\end{tabular}

Source: Own preparation, research results.

The results are also consistent with the studies by Neto et al., (2017) and Vieira et al., (2017) assuming there is no integral assistance to websites. As well as the study by Comin et al., (2016) in which it was found out an assistance average of $69.43 \%$.

The same occurs in the findings of Andrade (2014) whose research results from the analysis of the greatest Brazilian cities, and there is no full assistance, and the only exception was the city of Joinville. Andrade and Raupp (2017) acknowledge that the city of Joinville stands out for complying with the requirements of the IAL.

According to Bernardes, Santos, and Rover (2015) the place of mandatory information is not in compliance with the IAL, being present in other sections. The websites must keep the information updated, assuring its integrity (Brasil, 2011). Another example of discrepancy with Law are the Municipal Chambers of the greater Florianópolis, except for that of Florianópolis. It was observed that any type of demonstrative is almost imperceptible, as well as its location (Agostineto \& Raupp, 2010).

Comin et al., (2016) explain that the cities are obliged to disclose their information and a policy of improvement is necessary so that information is properly evidenced, ensuring effective social control. However, such control is not reached by people due to the disregard on the part of the rulers to render accounts.

\subsection{Correlation Analysis}

To analyze the influence between studied variables, first it was applied the Kolmogorov-Smirnov (KS) test to check if the sample has a normal distribution. The result obtained in KS test were higher than the critical values (or tabulated), indicating that the hypothesis of a normal distribution at the $10 \%$ level is rejected, according to Gujarati (2010).

With this, the non-parametric model of Sperman's correlation was used to measure the correlation between the following variables: Size of population and ranking, size of population and transparency, ranking and total revenue, transparency and total revenue. The obtained results can be observed in Table 4.

Given the results, it was observed there is no correlation between most populous cities and 
transparency in studied Municipal Chambers. A similar result was found by work of Neto et al., (2017) that investigated the transparency of most populous cities of Pernambuco.

Another research conducted by Comin et al., (2016) found the same result. They found out that smaller cities disclose more information.

Table 4. Existing correlation between analyzed variables.

\begin{tabular}{lll}
\hline Variables & Sig. & Correlation \\
\hline Size of population x transparency & $58.8 \%$ & No \\
Ranking X total revenue & $89 \%$ & No \\
Transparency x total revenue & $62.7 \%$ & No \\
Size of population x ranking & $1 \%$ & Yes \\
\hline
\end{tabular}

Source: Own preparation, research results

Continuing the analysis of analyzed variables it was also observed that the revenue of Municipal Chamber does not raise the ranking nor does it increase the transparency. There is no relation between them; for example, the Municipal Chamber can have relatively low revenue compared to the others, and be more transparent. Similarly, the Municipal Chamber can have high revenue and not be transparent. Consequently, regardless of whether the Municipal Chamber has more or less revenue, this does not influence its transparency level.

In studies by Cruz, Silva and Santos (2009) the results were similar between size of population and transparency levels. Nevertheless, the indicator of revenue and transparency showed a different situation compared to this study. This result can be compared with findings by Cruz et al., (2012) and Ribeiro and Zuccolotto (2012), where they state that transparency levels have a positive relationship with social-economic indicators of analyzed cities.

The results also showed that, from analyzed variables, only population size has influence in the ranking of Municipal Chambers of Pernambuco. This means that the larger the population size of a city, the grade of ranking tends to be $26 \%$ greater.

It was expected that more populous cities would have a higher transparency level, especially because those cities generate more revenue, and cities that had more revenue would more transparent, due to destination of public resources. However, the results were the opposite.

Furthermore, most portals of Municipal Chambers of Pernambuco are in disagreement with the Transparency Law, hurting the Principle of Openness. To Platt Neto et al., (2017) publishing this information is extremely important for effective social control in Public Administration, and the accessible use of those elements required by Law is indispensable.

Public Administration not only needs to make information available, but also offer tools to provide efficiency in research, incorporating web technology with the purpose of benefiting users (Andrade \& Raupp, 2017).

It is up to citizens who feel disrespected, to report to competent agencies in order to ensure that measures can be taken. To Andrade and Raupp (2017), Public Administration is 
responsible for punishing agencies that act in the noncompliance with the Law.

It is worth noting that it does not mean that information not found in websites is unavailable, but it could be in a place of difficult access, violating the Law, which makes it clear that information must be located in a place of easy access.

\section{Final Considerations}

The research assessed the compliance level to Law No. 12.527/2011 in Municipal Chambers of Pernambuco, in cities that have beyond 10.000 inhabitants.

The obtained results reached $30 \%$ of compliance in the ranking of most transparent ones, a value considered very low due to the obligation to disclose information in virtual environments with access to any interested user.

Thus, in a sample of 166 Municipal Chambers, only eleven disclosed all information required by the IAL, mentioned in paragraph 1 of Article 8. Raupp and Pinho (2014) believe that the lack of adequacy to the Information Access Lawis related to political rather than technical problems.

Moreover, from analyzed variables (Population Size and Ranking; Population Size and Transparency; Ranking and Total Revenue; Transparence and total Revenue) only Population Size and Ranking have a positive relationship.

Therefore, the compliance level to the Information Access Lawis still in a remote stage to reach transparency, as this Law has been in force since 2012, and public agencies should have already met the requirements imposed.

In order to achieve real adequacy of information in official websites, the State should penalize those agencies that fail to comply with what the Law establishes, by means of stricter inspection. To Bernardes, Santos, and Rover (2015) an electronic governance policy would be the ideal key to change this reality that is not very connected to citizens.

This research contributed to demonstrate the reality of Municipal Chambers of Pernambuco. The accountability culture is not a reality, considering that the proportion found in compliance level to Law was rather unsatisfactory.

\section{References}

Agostineto, R. C., \& Raupp, F. M. (2010). Prestação de contas por meio de portais eletrônicos: um estudo em câmaras municipais da Grande Florianópolis. Revista Universo Contábil, FURB, Blumenau, 6(3), 64-79. https://doi.org/10.4270/ruc.2010322

Andrade, R. et al. (2014). Transparência das informações públicas à luz da lei de acesso à informação: um estudo survey em câmaras municipais brasileiras.

Andrade, R. G., \& Raupp, F. M. (2017). Transparência do legislativo local à luz da Lei de Acesso à Informação: evidências empíricas a partir dos maiores municípios brasileiros. $\begin{array}{lllll}\text { Desenvolvimento em } & \text { Questão } & \text { [S.l.], } & \text { 15(41), }\end{array}$ https://doi.org/10.21527/2237-6453.2017.41.85-130 
Angélico, F. (2012). Lei de acesso à informação e seus possíveis desdobramentos à accountability democrática no Brasil. 139 f. 2012. Dissertação (Mestrado em Administração Pública) - Fundação Getúlio Vargas, São Paulo.

Arruda, A. F., \& Teles, J. S. (2010). A importância do controle social na fiscalização dos gastos públicos. Revista Razão Contábil \& Finanças, 1(1).

Bairral, M. A. C., Silva, A. H. C., \& Alves, F. J. D. S. (2015). Transparência no setor público: uma análise dos relatórios de gestão anuais de entidades públicas federais no ano de 2010. Revista de Administração Pública, 49(3), 643-675. https://doi.org/10.1590/0034-7612125158

Barros, L. M., \& Fonseca, M. W. (2014). A transparência fiscal eletrônica nos municípios do estado do paraná: avaliação do índice de transparência e as possíveis relações nesse processo. In: IX CONGRESSO ANPCONT, 2015, Curitiba. Anais... [S.1.]. Associação Nacional de Programas de Pós-Graduação em Ciências Contábeis.

Bernardes, M. B., Santos), M., \& Rover, A. J. (2015). Ranking das prefeituras da região Sul do Brasil: uma avaliação a partir de critérios estabelecidos na Lei de Acesso à Informação. Revista de Administração Pública, 49(3), 761-792. https://doi.org/10.1590/0034-7612119279

Brasil, Lei Complementar n. 131, 27 de maio de (2009). Acrescenta dispositivos à Lei Complementar $\mathrm{N}^{\mathrm{O}} 101$, de 4 de maio de 2000, que estabelece normas de finanças públicas voltadas para a responsabilidade na gestão fiscal e dá outras providências, a fim de determinar a disponibilização, em tempo real, de informações pormenorizadas sobre a execução orçamentária e financeira da União, dos Estados, do Distrito Federal e dos Municípios. Disponível em: <http://www.planalto.gov.br/ccivil_03/leis/lcp/lcp131.htm>. Acesso em: 25 de mar. 2017.

Brasil. C. (1988). Constituição da República Federativa do Brasil. Brasília, DF: Senado, 1988.

Brasil. Lei n. 12.527, de 18 de novembro de 2011. Regula o acesso a informações previsto no inciso XXXIII do art. $5^{\circ}$, no inciso II do $\S 3^{\circ}$ do art. 37 e no $\S 2^{\circ}$ do art. 216 da Constituição Federal; altera a Lei n. 8.112, de 11 de dezembro de 1990; revoga a Lei n. 11.111, de 5 de maio de 2005, e dispositivos da Lei n. 8.159, de 8 de janeiro de 1991; e dá outras providências. Diário Oficial da república Federativa do Brasil. Disponível em: <http://www.planalto.gov.br/ccivil_03/_ato2011-2014/2011/lei/112527.htm>. Acesso em: 22 fev. 2017.

Campos, A. M. (1990). Accountability: quando poderemos traduzi-la para o português? Revista de Administração Pública, Rio de Janeiro, 24(2), 30- 50, fev./abr. 1990.

Campos, R., Paiva, D., \& Gomes, S. (2013). Gestão da informação pública: um estudo sobre o Portal Transparência Goiás. Revista Sociedade e Estado, Brasília, 28(2), 421-446, maio/ago. https://doi.org/10.1590/S0102-69922013000200012

Comin, D. et al. (2016). A transparência ativa nos municípios de santa catarina: avaliação do índice de atendimento à lei de acesso à informação e suas determinantes. Revista Catarinense 
da Ciência Contábil, 15(46). https://doi.org/10.16930/2237-7662/rccc.v15n46p24-34

Creswell, J. W. (2010). Projeto de pesquisa métodos qualitativo, quantitativo e misto. In: Projeto de pesquisa métodos qualitativo, quantitativo e misto. Artmed.

Cruz, C. F. et al. (2012). Transparência da gestão pública municipal: um estudo a partir dos portais eletrônicos dos maiores municípios brasileiros. Revista de Administração Pública, 46(1), 153-176. https://doi.org/10.1590/S0034-76122012000100008

Cruz, C. F., Silva, L. M., \& Santos, R. (2009). Transparência da gestão fiscal: um estudo a partir dos portais eletrônicos dos maiores municípios do Estado do Rio de Janeiro. Revista Contabilidade, Gestão e Governança, Brasília, 12(3), 112-115, set./dez.

Gil, A. C. (2008). Métodos e técnicas de pesquisa social. 6. ed. Atlas.

Gujarati, D. N., \& Porter, D. C. (2011). Econometria Básica. 5. ed. Porto Alegre: AMGH, 924 p.

Hobold, J. P., \& Rosa, F. S. (2017). Análise da transparência pública nos portais eletrônicos dos municípios pertencentes à Amurel.

Hoch), A., Rigui, L. M., \& Silva, R. L. (2012). Desafios à concretização da transparência ativa na internet, à luz da lei de acesso à informação pública: análise dos portais dos tribunais regionais federais. Revista Direitos Emergentes na Sociedade Global, Santa Maria, 1(2), 257-286, jul./dez.

Jacques, F. V. S., Quintana, A. C., \& Macagnan, C. B. (2013) Transparência em Municípios da Região Sul do Brasil. In: EnANPAD 2013, Rio de Janeiro. Anais... [S.1.], 1-13.

Keunecke, L. P., Teles, J., \& Flach, L. (2011). Práticas de Accountability: uma análise do índice de transparência nos municípios mais populosos de Santa Catarina DOI: 10.5007/2175-8069.2011 v8n16p153. Revista Contemporânea de Contabilidade, 8(16), 153-174.

Marconi, M. A., \& Lakatos, E. M. (2003). Fundamentos de metodologia científica. 5. ed. São Paulo: Atlas.

Nunes, G. S. F. (2013). Avaliação da transparência pública à luz da legislação brasileira: um estudo nos municípios da Região Sul do Brasil. 2013. Tese (Doutorado em XXX) Universidade Federal de Santa Catarina.

Platt Neto, O. A. et al. (2007). Publicidade e transparência das contas públicas: obrigatoriedade e abrangência desses princípios na administração pública brasileira. Contabilidade Vista \& Revista, Belo Horizonte, 18(1), 75-94, jan./mar.

Raupp, F. M., \& Pinho, J. A. G. (2011). Prestação de contas por meio de portais eletrônicos de câmaras municipais: um estudo de caso em Santa Catarina antes e após a Lei da Transparência. Revista de Contabilidade do Mestrado em Ciências Contábeis da UERJ, 16(3), 81-98, set./dez. 


\section{Macrothink}

Journal of Public Administration and Governance ISSN 2161-7104 2018, Vol. 8, No. 2

Raupp, F. M., \& Pinho, J. A. G. (2013). Accountability em câmaras municipais: uma investigação em portais eletrônicos. R.adm., São Paulo, 48(4), 770-782, out./dez. https://doi.org/10.5700/rausp1120

Raupp, F. M., \& Pinho, J. A. G. (2014). Prestação de contas nos portais eletrônicos de Assembleias Legislativas: um estudo após a Lei de Acesso à Informação. Gestão \& Planejamento-G\&P, Salvador, 15(1).

Raupp, F. M., Andrade, R. G., \& Pinho, J. A. G. (2015). Em busca da transparência ativa em câmaras: uma investigação nos maiores municípios brasileiros. Anais do SemeAd-Seminários em Administração FEA-USP, 18.

Ribeiro, C. P. P., \& Zuccolotto, R. (2012). Fatores Determinantes da Transparência na Gestão Pública dos Municípios Brasileiros. In: ENAPG, 2012, São Paulo. Anais... [s. 1.]: 1 - 16.

Sacramento, A. R. S., \& Pinho, J. A. G. (2007). Transparência na administração pública: o que mudou depois da Lei de Responsabilidade Fiscal? Um estudo exploratório em seis Municípios da região metropolitana de salvador. Revista de Contabilidade da UFBA, Salvador, 1(1), 48-61 set./dez.

Silva Neto, J. H., Carvalho, J. R. M., \& Silva, E. E. D. (2017). Transparência nos portais dos municípios mais populosos do estado do pernambuco. IV Encontro Brasileiro de Administração Pública, João Pessoa/PB,..

Souza, F. J. V. et al. (2013). Índice de transparência municipal: um estudo nos municípios mais populosos do Rio Grande do Norte. Revista de Gestão, Finanças e Contabilidade, Salvador, 3(3), 94-113, set./dez.

Vieira et al. (2017). Análise do Grau de Aderência à Lei de Responsabilidade Fiscal e à Lei de Acesso à Informação nos Municípios do Estado do Rio Grande do Sul com Mais de 50 Mil Habitantes. Desenvolvimento em Questão [S.l.], 15(41), 151512121111121

\section{Copyright Disclaimer}

Copyright for this article is retained by the author(s), with first publication rights granted to the journal.

This is an open-access article distributed under the terms and conditions of the Creative Commons Attribution license (http://creativecommons.org/licenses/by/4.0/). 